\title{
BUILDING CORPORATE SOCIAL RESPONSIBILITY INTO STRATEGY
}

\author{
Jeremy Galbreath \\ Graduate School of Business \\ Curtin University of Technology \\ 78 Murray Street \\ Perth 6000 \\ Western Australia \\ +61 8 9266-3568 (voice) \\ +61 8 9266-3368 (fax) \\ jeremy.galbreath@gsb.curtin.edu.au
}

\begin{abstract}
Autobiographical note:
Jeremy Galbreath is a Postdoctoral Research Fellow and Senior Lecturer at the Graduate School of Business, Curtin University of Technology. He is the author of nearly 60 articles, including three award winners, and has written chapters for strategic management, business ethics, and corporate sustainability texts. His work has appeared in Corporate Governance, European Business Review, Journal of Business Ethics, Journal of Business Research, International Journal of Electronic Customer Relationship Management, International Journal of Information Technology and Management, International Journal of Organizational Analysis and Management Decision, as well as other journals and conference proceedings.
\end{abstract}




\title{
BUILDING CORPORATE SOCIAL RESPONSIBILITY INTO STRATEGY
}

\author{
Abstract \\ Purpose - To explore how corporate social responsibility (CSR) can be effectively built \\ into firm strategy.
}

Design/methodology/approach - By drawing upon classics work in the field, this paper first offers conceptual discussion and then systematically develops a means of incorporating CSR into strategy.

Findings - Common approaches to CSR, such as PR campaigns, codes of ethics and triple bottom line reports are far to removed from strategy. To counter common and generally non-strategic approaches, a framework is offered which demonstrates that CSR can be linked integrally with strategy, and highlights an approach to consider CSR across six dimensions of firm strategy.

Practical implications - Firms do not have to respond reactively towards CSR nor do they have to struggle with understanding the strategic implications of CSR. As this paper demonstrates, examining CSR in the context of firm strategy is both possible and increasingly necessary to developing competitive advantage in the current environment. Originality/value - The value of the paper rests in the treatment of CSR as an issue that is strategic, rather than one that is problematic or potentially a threat. By doing so, firms are offered a means to take a much more proactive approach to CSR than previously discussed.

Keywords - Corporate social responsibility, social issues, strategic issues, strategy Paper Type - Conceptual paper 


\section{BUILDING CORPORATE SOCIAL RESPONSIBILITY INTO STRATEGY}

\subsection{INTRODUCTION}

For decades, corporate social responsibility (CSR) has been a subject of intense debate among scholars and practitioners (Carroll, 1999; Pearce and Doh, 2005). Discussions have generally focused on the role of business in society and the nature of a firm's social responsibilities. More recent treatments have progressed towards theory development as well as empirical tests of the relationship between CSR and firm performance (Orlitzky et al., 2003; Aguilera et al., 2007). However, at the practical level, there appears to remain much confusion with respect to how to build or integrate CSR into the overall strategy of the firm.

By way of example, while CEOs acknowledge that addressing societal expectations is an important consideration for competitive success, they appear to be struggling with just how to build CSR into corporate strategy (Hirschland, 2005; McKinsey and Company, 2006). Indeed, recent reports reveal that almost six out of ten organizations have no strategy for CSR while many companies are unclear as to how to adequately anticipate which social issues will affect their overall strategy (The Work Foundation, 2002; McKinsey and Company, 2006). Where efforts are made with respect to CSR strategies, typical approaches appear to be weak in that they fail to capture the fundamental purposes of strategy.

Typical approaches to CSR include developing corporate codes of ethics, preparing triple bottom line reports and launching public relations campaigns that highlight a given socially responsible 'act' (Vyakarnam, 1992; Weaver et al., 1999). According to worldwide director of management consulting firm McKinsey and Company, Ian Davis, such approaches are too limited, too defensive and are too disconnected from strategy (Davis, 2005). In the first instance, a code of ethics mainly 
addresses personal behavior, not strategy (Hosmer, 1994). With respect to triple bottom line reporting efforts are focused mainly on information transparency rather than on corporate strategy (Vyakarnam, 1992; Weaver et al., 1999). Lastly, public relations campaigns that contain CSR content have been labeled as a non-strategic corporate 'window dressing' exercise (Weaver et al., 1999). How then, might CSR be built into strategy and how might this lead to a better performing, more competitive and responsible firm?

In order to examine an important, but rarely holistically explored topic in the stream, the remainder of this paper will discuss a means for addressing the CSR-strategy gap. To do so, background on strategy is offered first, which sets the stage for its use in this paper. Next, the concept of social issues and some basic discrepancies between this concept and strategy is described, which is important to the development of the CSRstrategy discussion. CSR is then framed within the context of the six fundamental dimensions of strategy. Finally, implications and concluding remarks are provided.

\subsection{WHAT IS STRATEGY?}

Drawing upon the work of several scholars (Ansoff, 1965; Learned et al., 1969; Andrews, 1971; Porter, 1980, 1985; Wernerfelt, 1984; Barney, 1991), for this paper, strategy is concerned with understanding and addressing issues that impact on a firm's ability to achieve its mission, so that products/services can be produced to meet the needs of the markets it serves through effective resource configuration, in order to build and sustain competitive advantage. Thus, strategy is conceptualized as: 1) what is a firm trying to achieve in the long term (mission); 2) what internal and external issues impact on the firm's ability to achieve its mission (strategic issues); 3) which markets should a firm compete in (markets); 4) what products/services are needed to offer customers in the chosen markets (customer needs); 5) what internal resources (assets, skills, competencies, 
relationships, finance, facilities) are necessary in order to compete (resources); and 6) how can a firm perform better than the competition (competitive advantage).

In this paper, the interest is in exploring how CSR fits into these six fundamental dimensions of strategy, for the overall purpose of weaving CSR into the strategy making function of the firm. However, before elucidated, additional concepts need to be discussed and clarified; namely, the social responsibilities of firms versus social issues. The reason being is that while closely linked, social responsibilities are not the same as social issues. More specifically, as will be demonstrated, social responsibilities are the expectations that society places on firms while social issues are factors to which these responsibilities are tied, factors that not only can affect a firm's ability to meet its objectives, but can ultimately affect their social responsibilities as well. This is an important distinction to recognise and has implications for strategy.

\subsection{SOCIAL RESPONSIBILITIES VERSUS SOCIAL ISSUES}

According to Friedman (1970), the only social responsibility of business firms is to maximize profits. By fulfilling this economic charter, Friedman (1970) believes that the firm does its part in meeting societal welfare, as opposed to what governments, social service organisations, educational institutions, non-profits and the like should do in their role to meet societal welfare.

After the publication of Friedman's (1970) thesis, management scholars began to develop theoretical rigor around the social responsibilities of the firm. In the late 1970s, Carroll (1979) offered one of the first - and perhaps still the most widely accepted conceptualisations of CSR (Matten and Crane, 2005). Carroll's (1979) model conceptualises the responsibilities of the firm to include: 1) the economic responsibility to generate profits; 2) the legal responsibility to comply by local, state, federal and relevant international laws; 3) the ethical responsibility to meet other social expectations, not 
written as law (e.g., avoiding harm or social injury, respecting moral rights of individuals, doing what is right, just, fair); and 4) the discretionary responsibility to meet additional behaviours and activities that society finds desirable (e.g., philanthropic initiatives such as contributing money to various kinds of social or cultural enterprises).

Beyond Carroll (1979), other academic thought also equates the role of business in society with responsibilities. For example, stakeholder theory argues that firms have responsibilities to various stakeholders, including those internal and external to the firm (Freeman, 1984; Clarkson, 1995; Donaldson and Preston, 1995). Similarly, corporate citizenship also conceptualises the firm's responsibilities, although this emerging field tends to align somewhat with Carroll's (1979, 1991) work (Maignan et al., 1999; Windsor, 2001; Dawkins, 2002; Windsor, 2006). Thus, the common theme among the fields of CSR, stakeholder theory and even corporate citizenship is that a firm's various responsibilities define how it fulfils the expectations placed on it by society (Carroll, 1979, 1999; Windsor, 2001).

The definitions of the social responsibilities of firms coming from Friedman (1970), Carroll (1979), stakeholder theory and corporate citizenship are largely normative: they describe what firms should do (or not do) in terms of their societal responsibilities (Rodriguez et al., 2002). In this sense, these definitions help to describe what the 'firm side’ of the social contract (Donaldson and Dunfee, 1994; Donaldson and Dunfee, 1999) between business and society consists of. On one hand, the 'formal' social contract defines a firm's explicit responsibilities, including generating returns for shareholders, obeying laws and regulations, creating jobs, paying taxes and honouring private contracts. On the other hand, the 'semiformal' social contract reflects society's implicit expectations. Here, society's unspoken expectations of firms include responsibilities such as adherence to global labour and environmental standards (e.g., SA 8000, AA 1000, ISO 14031) that 
are not required by law, triple bottom-line reporting, following industry norms and codes of conduct, fulfilling brand promises and contributing philanthropically to the community.

Additionally, the widely recognised conceptualisations of CSR described in this paper are cross-sectional in that they 'look inside' a firm at a given point in time and reveal the degree to which a firm is acting socially responsible - whether they are fulfilling their social responsibilities. While appropriate for a definitional understanding of the phenomenon and to use as a guide to test the relationship between CSR and firm performance, such conceptualisations offer little insight into how CSR can be integrally linked with firm strategy or what the firm can do to better understand this link. Importantly, this link presupposes issues, social or otherwise.

A social issue is anything that is found wrong with society. It is a controversial point, which is an object for social discussion. However, the concept is most often used for aspects of topics or themes that are under intense public debate. More specifically, a social issue has four interrelated aspects. First, a social issue is not an individual issue (although it may arise from an individual). Many people in society must recognize that something is wrong or that there is a problem. Second, a social issue is not a universal issue in that it is located within a particular social context at a particular point in time and history. Third, to say or observe that something is wrong or there is a problem in society assumes that there is an idea of the way things 'should be'. Lastly, if there is a recognized way that things should be, then there is the possibility that the resolution of a social issue is achievable by some means. In short, a social issue in the above context is based on classic sociology definitions and theories of social change (Merton, 1957; Ogburn, 1964).

Within the business and society literature, scholars have addressed the social issues concept, predominately through the life-cycle approach (Lamertz et al., 2003). 
Although several definitions exist, a widely accepted definition in the life-cycle tradition describes social issues as:

Social problems that may exist objectively but become 'issues' requiring managerial attention when they are defined as being problematic to society or an institution within society by a group of actors or stakeholders capable of influencing either governmental action or company policy. (Mahon and Waddock, 1992, p. 20; emphasis added)

In this definition, the implication is that problems of a social nature exist at the societal level (but not necessarily at the organizational level) that are eventually elevated to the 'status' of a social issue by the actions of various actors, including stakeholders. However, such a definition does not address how these social problems and issues might be an opportunity for the firm and thus, is problematic with respect to the concept of strategy.

Based on theories of strategy, corporate managers regard the internal and external environments in terms of 'opportunities' and 'threats' (Learned et al., 1969; Andrews, 1971). As the conception of social issues mostly neglects the opportunities of social development for firms, it is necessary to consider the importance of strategic issues to managers. According to Ansoff (1980, p. 133), “a strategic issue is a forthcoming development, either inside, or outside the organization, which is likely to have an important impact on the ability of the enterprise to meet its objectives”.

Overall, given Ansoff's (1980) definition of a strategic issue, a firm faces a potential diversity of issues and represents the variety of factors that need to be identified and assessed in internal and external environments, social issues being just one. Therefore, viewing social issues as strategic issues is important in order to more fully integrate CSR into strategy. The examination of social issues is best framed within the context of strategy because it is the role of strategy to identify, assess and respond to such issues (Andrews, 1971; Schendel and Hofer, 1979). 


\subsection{BUILDING CSR INTO STRATEGY}

Strategy serves as a foundation for a business firm's creation, while establishing its position in the market, its competitiveness and its on-going existence. To achieve these aspects, planning/programming is required in order to craft or formulate and renew/change strategy as conditions warrant (Andrews, 1971; Steiner, 1979; Mintzberg, 1987). This planning/programming largely takes place within the context of the six strategy dimensions previously outlined. Thus, in this section, CSR is explored within each dimension (Figure 1). However, this exploration is not process-driven. That is, the interest is in how CSR might be more fully integrated into the strategy of the firm, not in what steps a firm should take to formulate strategy. In this sense, the following discussion is not sequential but rather examines the constituent components of strategy and how CSR might be built into each component. Following such an approach would be expected to lead to a tighter integration of CSR with strategy, but the purpose is not to posit the correct path to take or process to follow. In fact, integrating CSR more fully with strategy is likely to be an emergent pattern over time, rather than a time-bound, easily prescribed path (cf. Carlisle and Faulkner, 2004).

\subsection{Firm mission}

Firm mission is a “declaration of an organization’s fundamental purpose: why it exists, how it sees itself, what it wishes to do, its beliefs and its long-term aspirations” (Bennett, 1996, p. 18). Thus, mission is a statement of intent. Given that mission signals to shareholders, investors, stakeholders and society a given firm's intent (Pearce and David, 1987), the following aspect of the CSR-strategy relationship is offered for consideration.

Since the writings of Marshall (1919, 1920), industry has been considered an appropriate level of aggregation for analyzing the role of competition in market economies (Bloch and Finch, 2005). Beyond a Marshallian view, Porter (1980) identifies 
strategic groups and industry 'clusters', which are also important levels in the analysis of competition. Industry, strategic groups and clusters are vital to mission development in that they give firms a baseline or starting point for identity (Peteraf and Shanely, 1997). Furthermore, industry, strategic groups and clusters give context to the various considerations for competing such as capital requirements, fixed versus variable costs, degree of rivalry, advertising, scale economies and location, among others (Bain, 1959; Porter, 1980, 1985).

Similarly, although some social issues may be common (e.g., energy conservation, recycling) to nearly all firms, they can be very different given a divergence of stakeholder, NGO and other social actor expectations impacting on a given industry (Logsdon and Wood, 2002; Davies, 2003; Aguilera et al., 2007). Thus, a firm with the mission of building the most fuel efficient cars in the world who is, at the same time, dedicating scarce company resources to explore how to solve teenage smoking because it is a social issue, reflects a disconnect between CSR and its mission, and a disconnect between a social issue and a strategic issue for that firm. According to Porter (1996), strategy is as much about what not to do, as it is what to do - it is descriptively wrong to suggest that a given firm should address all social issues (cf. Sethi, 2003).

More specifically, CSR should be strategized in the context of what the firm is trying to achieve, which takes into consideration specific actor expectations, industry and other levels of competitive reference (e.g., strategic group). Such an approach is vital to building CSR into strategy in a way that reflects its actual business importance to the firm's mission (Burke and Logsdon, 1996). By way of example, some firms signal that CSR is a fundamental purpose - mission - of their existence. As part of its mission, The Body Shop makes cosmetics that do not hurt animals. Here, The Body Shop has addressed a social issue - animal cruelty - through the very core of their business: developing the 
highest quality, innovative, effective and safe cosmetic products. Ben \& Jerry’s Homemade Ice Cream, on the other hand, has a three-part mission: product, economic and social. Ben \& Jerry's mission can be further expressed through the following description:

- Capitalism and the wealth it produces do not create opportunity for everyone equally. We recognize that the gap between the rich and the poor is wider than at anytime since the 1920's.We strive to create economic opportunities for those who have been denied them and to advance new models of economic justice that are sustainable and replicable.

- By definition, the manufacturing of products creates waste. We strive to minimize our negative impact on the environment.

- The growing of food is overly reliant on the use of toxic chemicals and other methods that are unsustainable. We support sustainable and safe methods of food production that reduce environmental degradation, maintain the productivity of the land over time, and support the economic viability of family farms and rural communities.

- We seek and support non-violent ways to achieve peace and justice. We believe government resources are more productively used in meeting human needs than in building and maintaining weapons systems.

- We strive to show a deep respect for human beings inside and outside our company and for the communities in which they live. ${ }^{1}$

Clearly, to Ben \& Jerry's, CSR is its mission. However, finding the right balance between mission and the level of CSR is not always easy. An imbalance can lead to a firm being spread too thin between its economic charter and other social responsibilities, thus raising concerns about long-term viability, given finite resources (Pearce and Doh, 2005). 


\subsection{Strategic issues}

Building CSR in the fundamental purpose of the firm - its mission - does not necessarily happen without proper reflection and understanding of the environment (and the personal values and convictions of a firm's top leaders). Understanding the environment and its implications for the firm rests within the domain of strategy. Andrews (1971) and Ansoff (1980) posit that issues that firms must address consist of those that are both internal and external. However, while there are many issues to consider, not all are strategic. Ansoff (1980) argues that for an issue to be strategic, it must be a forthcoming development at a level of importance such that the issue can significantly impact on a firm's ability to meet its objectives. To identify issues of this type, research and analysis, using a variety of techniques, is the prescribed course of action (Andrews, 1971; Porter, 1980). Given that the identification and understanding of strategic issues is primarily a research and analysis function of strategy, from a CSR perspective, the unit of analysis and techniques of analysis are particularly important to assess the impact of factors of a social nature.

The unit of analysis is social-related problems and issues. According to the definition of Mahon and Waddock (1992), social problems can objectively exist before they become social issues. In this sense, strategically and opportunistically, there are unmet social needs and social issues. Unmet social needs are social problems that are developing in society but have not yet been officially defined or propagated to the level of an issue by social actors or stakeholders. On the other hand, social issues are 'official' in the sense that they have reached, through various actor actions, the formal attention of governmental policy makers and corporate managers. Thus, analysis of these two socialrelated factors is important to address their strategic significance.

In order to analyse and assess unmet social needs, a number of techniques are potentially useful. Media coverage and expert testimony, for example, are important 
mediums to monitor in that they can disclose early signals of unmet social needs while scenario planning is a useful technique in that it enables firms to explore future scenarios that take into account shifts in consumer patterns, reactions of competitors and the possibility of litigation and regulation (Kahaner, 1996; Swartz, 1996). By example, growing concern over obesity in the United States was evident in the media at least five years before the first warning by the U.S. Surgeon General that obesity had become an epidemic (Lawrence, 2004). Furthermore, expert testimony, such as that of Harvard University's Walter Willett, explained that [childhood] obesity was in part linked to the marketing of 'junk food' (Lawrence, 2004). Thus, the problem of obesity was shifting from individual responsibility to external, environmental factors including corporate marketing. In the case of obesity, many fast food restaurants, for example, have been caught off guard and some lawsuits encountered as a result, damaging reputations and costing significant resources (Burros, 2006). However, through techniques such as media monitoring, analysis of expert testimony and scenario planning, the shift might have been anticipated much earlier and an unmet social need identified.

\subsection{Markets}

A market consists of the set of all actual and potential buyers of a product or service (Kotler and Armstrong, 2005). However, according to Cahill (1997), for a firm to strategically address markets, they must address specific target markets. A target market is a group of buyers for whom an offering should be appropriate and to whom the firm

will direct the major part of its marketing time, resources and attention. Kotler and Armstrong (2005) suggest that target marketing is about analyzing and assessing each market segment's attractiveness and selecting one or more segments to focus on. This has ramifications for the CSR-strategy relationship. 
Assessing markets for specific target opportunities can be a complex exercise although, in general, marketing theory suggests that in order to develop market segment profiles that can be assessed strategically, a variety of variables need to be explored including demographic, geographic, psychographic and behaviorist variables (Bearden et al., 2003; Kotler and Armstrong, 2005). Once these variables have been assessed, choices have to be made with respect to which segments to ultimately serve. Here, evaluation includes the market potential of each segment (i.e., growth of the segment), the firm's sales potential (i.e., market share), competitive assessment (i.e., nature of competition, competitive rivalry) and cost estimates/resource requirements (i.e., ability to achieve competitive advantage). Although simplistically described here, these are the basic requirements that marketing theory prescribes for assessing, evaluating and choosing which target markets the firm will serve. However, an additional variable needs to be considered when assessing market segments strategically; namely, a 'social dynamics' variable.

Social dynamics refers to the underlying expectations that a given market segment places on the role of business in society currently or possibly in the future (thus, 'dynamic' is used to reflect the potential changing nature of societal expectations). For example, in the food and beverage industry, consumer expectations for detailed nutrition facts on packaging has risen in recent years which has implications for how products are developed and marketed. Is such demand across all food and beverage segments, or only certain ones? Similarly, in the apparel industry, more and more consumers are interested in where and how clothes are manufactured given the backlash against 'sweat shop' practices, which has implications for manufacturing location, supply chain standards and employee policies. Is such interest across all apparel segments, or only certain ones? Overall, for firms to more adequately build CSR into strategy, the social dynamics 
variable becomes important in terms of understanding the current and emerging characteristics of target markets. Further, if assessing various social factors of a given market segment is important to the general understanding of that segment, then it is also important in terms of understanding specific target customer needs.

\subsection{Customer needs}

Some scholars have suggested that the sole purpose of any firm is to create value for the customer (e.g., Drucker, 1954; Slater, 1997). Although agency theory challenges such a purpose (see Khurana et al., 2005), creating value for customers is certainly a strategic function of business. How does the firm create customer value? Multiple answers have been given in the literature to answer the question. For purposes here, two key aspects are addressed: 1) market orientation and 2) innovation.

Market orientation has been identified in the marketing and strategic management literature as important to firm strategy (Kohli and Jaworski, 1990; Hult and Ketchen, 2001). Market orientation, as a construct, grew out of the idea that firms who effectively implement the marketing concept will achieve better corporate performance than less market-orientated rivals (Sheth et al., 1988; Kohli and Jaworski, 1990; Kotler, 1991). Although variations exist, a general conception of market orientation includes a customer orientation dimension, a competitor orientation dimension and a market information sharing dimension. Of particular interest is the customer orientation dimension.

Customer orientation is defined as the actions designed to understand the current and latent needs of customers in the target markets served so as to create superior value for them (Narver and Slater, 1990). Here, a variety of actions are prescribed in order to learn about the current and latent needs of customers and the wider forces that shape those needs (Day, 1999). As pointed out, social-related forces are increasingly shaping markets and, by extension, the customer needs that are developing. The analysis of unmet social 
needs and social issues appears to be just as important to the understanding of customer needs as traditional factors, such as age, income, personality characteristics, usage rates, education, price sensitivity and the like. However, understanding target customers and their current and latent needs is not the same as creating superior value for them. In order to create superior value, firms must construct offerings that appeal to customers, are more attractive than competitors and that ultimately offer benefits that exceed the buyers payment in a purchase exchange (Zeithaml, 1988; Normann and Ramirez, 1993; Gale, 1994). Such offerings are the result of innovation (Slater, 1997).

Evolutionary/Austrian economics has long described innovation as a driving force behind economic growth and competitive success (Schumpeter, 1934; Nelson and Winter, 1982; Jacobson, 1992). Firms can embrace unmet social needs and social issues as a real opportunity for innovation, rather than treating them as a threat to take lightly or as factors which they can ignore. Here, by leveraging knowledge gained from target markets, target customer needs and the unmet social needs and/or social issues directly affecting those markets and customers, firms can explore the opportunity to change the competitive playing field, for example, by introducing entirely new consumer offerings, developing new processes or creating new market segments directly aimed at fulfilling an unmet social need or a social issue (cf. Schumpter, 1934; Jacobson, 1992; Hill and Deeds, 1996; Chan Kim and Mauborgne, 2004). In this context, a firm can fulfill its responsibilities by meeting a societal demand, while in the process creating both economic benefit and consumer utility (cf. McWilliams and Siegel, 2001; Mackey et al., 2007; Husted and Salazar, 2006).

\subsection{Resources}

A major facet of strategy is concerned with matching internal resources with a changing external environment in a way that enhances organizational performance over time 
(Learned et al., 1969; Andrews, 1971; Hamel and Prahalad, 1994). In terms of the internal aspect, resources have been described as activities (Porter, 1985), assets (Dierickx and Cool, 1989), core competencies (Prahalad and Hamel, 1990), capabilities (Day, 1994) and dynamic capabilities (Teece et al., 1997). Generally, resources consist of the factors necessary to create, operate and sustain a firm, be they tangible or intangible factors (Wernerfelt, 1984; Barney, 1991). Although many such resources exist, the important point of departure for resources in a CSR-strategy context rests with resource specificity.

Specificity refers to the degree to which resources are leveraged to capture or internalize at least some benefits for engaging in CSR that are specific to the firm, rather than simply creating collective goods which can be shared by others in the industry, community or society at large (Rumelt, 1980; Porter, 1985). In this sense, firms not only take ownership for fulfilling their social responsibilities, but also capture exclusive benefits that can be of strategic value.

To demonstrate, assume a firm contributes money to a local symphony orchestra which benefits symphony-goers and others in the community who feel pride in or value classical music. Neither of these benefits is specific to the firm who makes the donation because there is no exclusive enjoyment (or benefit) granted to the firm. Similarly, if a firm produces chemical products and in the process uses waste water treatment technology to protect the environment, public benefits are created which are available to the entire community. Here, the firm only benefits to the extent that it also shares in a healthier environment and avoids fines or censure for failing to comply with federal pollution standards.

On the other hand, consider a manufacturing firm that invests resources in cogeneration technology which recaptures heat discharged through smokestacks and converts it to energy, substituting electrical power purchased from the local utility. In this 
case, the benefits of cogeneration are highly specific to the firm in the form of energy costs saved. The benefit spillover to the public is the firm's contribution to aggregate energy conservation. In this example, the firm not only acts in a socially responsible manner (thereby meeting societal expectations for conserving energy), but by addressing a social issue through the use of innovative technology, also creates benefits that are highly context specific.

\subsection{Competitive advantage}

The last strategy dimension, competitive advantage (CA), is largely concerned with how a firm will compete so as to earn and sustain superior performance (Porter, 1980, 1991; Barney, 1991). The two dominant perspectives of CA include the positioning approach (Porter, 1980) and the resource-based view (RBV) of the firm (Wernerfelt, 1984; Barney, 1991). In the first instance, Porter (1980) describes two generic strategies (or positions) firms can pursue to gain, and possibly sustain, a CA: cost position and differentiation position. Essentially, the position approach to CA is concerned with producing a product at a lower unit cost than competitors, thereby generating higher returns, or with producing a product that is differentiated from competitors, one in which consumers are willing to pay a higher price.

Considering the positioning approach in light of unmet social needs and social issues, it is possible to pursue a strategy focused on capturing a market aimed at the social dimension (McWilliams and Siegel, 2001). A good example is firms who are finding ways to differentiate products in light of the obesity issue. For example, Whole Foods Market has become the largest retail food chain in the world specializing in health and organic foods. Whole Foods Market is not only meeting the welfare of society and addressing a social issue by offering differentiated products designed to properly nourish and maintain the health of individuals, but is consistently growing sales and profits, 
demonstrating that what is good for society does not have to be a burden to firms and what is good for firms does not have to be a burden to society (Burke and Logsdon, 1996; Husted and Salazar, 2006).

With respect to the RBV, the main emphasis is on creating, possibly acquiring and leveraging resources that are causally ambiguous, socially complex, difficult to imitate and that pass through critical time-dependent stages (Dierickx and Cool, 1989; Barney, 1991; Amit and Schoemaker, 1993). One way to create such resources is through demonstrating responsible management practices with the firm's stakeholders (which, as noted, can include addressing unmet social needs and social issues). For example, firms who are able to engage stakeholders beyond market transactions - which can be imitated by competitors - to develop long-term relationships create socially complex, timedependent resources based on reputation and trust; reputation and trust can enhance the value of these relationships, which is not so easily imitated by competitors (Fombrun and Shanley, 1990; Barney and Hansen, 1994).

According to Barney (1991), developing socially complex, time-dependent and inimitable resources, such as stakeholder relationships, can lead to CA and be a source of superior performance. Similarly, Jones (1995) argues that firms who develop relationships with stakeholders based on honesty, mutual trust and cooperation are in a better position to gain an advantage over firms that do not. The reason being is that developing trust and cooperation between stakeholders takes time, which in turn leads to mutually beneficial value exchanges. Such exchanges are beneficial to the firm's stakeholders in that they receive value in excess of the effort required to engage in the exchanges; to the firm, they gain advantages that lead to improved performance (Jones, 1995; Prahalad, 1997). Further, the ethical characteristics of honesty and trust reduce transaction costs because fewer protective devices are needed if the firm has trustworthy agents and less time is 
spent in negotiation if initial claims are truthful (Williamson, 1985; Hosmer, 1995). Thus, the costs of an option based on these characteristics are lowered, so that it may become the preferred option, especially where transaction costs are high relative to other costs. In this sense, trustworthiness has been argued to be a source of CA (Barney and Hansen, 1994). Logically, this has strategic implications for the ethical responsibility of the firm per Carroll's (1979) conceptualization of CSR.

Stakeholder theory also recognises that firms have explicit costs (e.g., payments to bondholders) and implicit costs (e.g., environmental costs, human resource costs). Stakeholder theory predicts that if firms try to lower their implicit costs by acting socially irresponsible (e.g., not investing in pollution control systems, treating employees poorly) they will actually incur higher explicit costs, which can result in a competitive disadvantage. Reflecting this logic, Alexander and Buchholz (1982) argue that demonstrating high levels of responsibility towards stakeholders is an indicator of superior management skill, which leads to lower explicit costs. Additionally, the actual costs of stakeholder management versus the benefits may be minimal. For example, enlightened employee management policies may have a relatively low cost, but the gains in productivity, morale and retention can yield substantial performance advantages over less responsible firms (Huselid, 1995).

\subsection{IMPLICATIONS}

Corporate executives acknowledge that CSR is an important consideration for driving success. However, at the same time they admit to struggling with uncertainty about how to anticipate which unmet social needs or social issues will affect their firms or how to develop corresponding 'win-win’ strategies. Similarly, from a scholarly perspective, much has been written to suggest that CSR is vital to competitive success; however, efforts have predominately focused on conceptual and theoretical advancements and empirical tests 
between CSR and firm performance. Unfortunately, this leaves a gap with respect to CSR and strategy. If an assumption is made that CSR is important to competitiveness, and if strategy serves as a foundation for a business firm's creation, while establishing its position in the market, its competitiveness and its on-going existence, then placing CSR within the context of strategy seems vital. Thus, an attempt at elaborating this relationship surfaces a few important implications.

First, CSR should not be viewed solely in terms of the responsibilities firms assume toward society or to whom they are responsible. Normatively postulating, for example, that firms have an economic responsibility to generate profits or a legal responsibility to obey appropriate laws or that firms have a responsibility to meet the needs of various stakeholder groups (and who those groups are) does not describe how they can do so in a strategic manner. What has been suggested is that in order to understand CSR strategically, unmet social needs and social issues, as well as the responsibilities firms assume toward society, need to be considered individually - and corporately. This is necessary so that CSR can be more accurately addressed within the fundamental dimensions of strategy.

This leads to the second implication and a question: To what degree does CSR have to be built into strategy before it can be considered 'strategic'? In the life of a company, a variety of different opportunities or threats are continually faced and decisions made to address them. At any given point in time one aspect of the six dimensions of strategy described in this chapter might be more important than others. Furthermore, some scholars have connected 'strategic' CSR with contributing slack resources (i.e., profit spending) to societal and community needs that are tied to organizational objectives and strategy, such as philanthropy, sponsorships and cause-related marketing (Mullen, 1997; Lantos, 2002; Porter and Kramer, 2002). Strategically, this is a narrow view and is 
predominately tied only to the discretionary (philanthropic) component of Carroll's (1979) conceptualization of CSR.

As demonstrated in this paper, CSR is not an organizational phenomenon strategically confined to a narrow dimension within the firm. In fact, when taking corporate responsibilities, unmet social needs and social issues into consideration, synergies develop that are important for several dimensions of strategy. For example, while the economic responsibility to produce profits constitutes part of the firm's formal social contract, by exploring unmet social needs and social issues through strategy dimensions such as markets served, customer needs and resources required to compete, a firm not only can address social opportunities that generate profits (thereby meeting its economic responsibility to shareholders), but can offer societal benefits as well (Burke and Logsdon, 1996; Husted and Salazar, 2006). This implies that 'strategic' CSR is far more than an ad-hoc approach or a bolt on to strategy or something that is strategic only when viewed within the realm of a singular dimension of a firm's responsibilities, such as the discretionary responsibility. Rather, when considered in light of the six dimensions described in this chapter, CSR can be more fully integrated into corporate strategy.

Lastly, mounting research evidence suggests that an increasing number of actors, both internal and external to the firm, are placing more and more demands on firms' social responsibilities and how they address factors of a social nature (Paine, 2002; Aguilera et al., 2007). Unfortunately, companies are not necessarily following suite. For example, nearly 50 percent of companies surveyed in a recent study report that they have substantial room for improvement with respect to CSR (McKinsey and Company, 2006). The following is suggested.

First, contrary to some views (e.g., Murray and Montanari, 1986; Lantos, 2002), corporate executives - not marketing or public relations departments - should take the 
lead role in developing CSR and integrating it with the firm's strategy, while developing a culture that is highly attuned to the social factors that might impact on the firm. The reason being is that it is corporate executives who ultimately have to answer to society, shareholders and other stakeholders about decisions made and strategies taken. This approach is consistent with the role of executives described in the literature (Barnard, 1938; Andrews, 1971). Second, facing and addressing social factors is not simply acting 'responsibly'; it is related to what markets to serve, what offerings are necessary to meet and exceed customer needs, how to gain a competitive advantage, among other dimensions of strategy, as well as to costs and profitability. It is also related to corporate credibility, acceptance and support, resulting in a firm's freedom to act and implement its strategies. Finally, typical approaches firms take towards CSR are based on producing annual social and environmental reports and the issuing of corporate policies on ethical issues (Davis, 2005). Such approaches are too limited, too defensive and too disconnected from corporate strategy. As described in this chapter, CSR does not have to be confined to an altruistic end to strategy (i.e., philanthropy) or to an ethical obligation (i.e., code of conduct). Rather, CSR can be given due consideration across six dimensions of corporate strategy, contributing ultimately to good management practice, economic benefit and societal welfare.

\subsection{CONCLUSION}

Business firms are the economic engine of society and the making of profits is a social responsibility (Carroll, 1979; Henderson, 2005). However, in the current climate, issues of a social nature are bearing on firms to the point that CSR appears to be the new battle ground for competitive success (Porter and Kramer, 2006). If this is true, then firms not only need be concerned about how to best meet the interests of their shareholders, but also the interests of society at large. In this sense, strategy takes on significant meaning not 
only with respect to fulfilling social responsibilities and the development of firms, but also with respect to the development and sustainability of society/nations (Raimond, 1996; Rodriguez et al., 2002) (Figure 2). Firms who better understand their social responsibilities and who begin to more adequately explore how they can build CSR into strategy are likely to reap the rewards of improved competitive positions in the future, to the benefit of their shareholders, but also to the benefit of society at large.

In order to more strategically address CSR, this paper made an argument that firms need to consider six strategy dimensions: 1) firm mission; 2) strategic issues; 3) markets; 4) customer needs; 5) resources; and 6) competitive advantage. As strategy is concerned with understanding and addressing issues that impact on a firm's ability to achieve its mission, so that products/services can be produced to meet the needs of the markets it serves through effective resource configuration, in order to build and sustain competitive advantage, considering CSR in light of these dimensions offers a means to systematically explore ways in which social responsibilities can be built into strategy. Otherwise, firms run the risk of equating CSR with codes of ethics, triple bottom line reports and public relations campaigns, for example. Such approaches are too limited, too defensive and are too disconnected from strategy. 


\section{ENDNOTES}

1. As described on Ben \& Jerry's website, http://www.benjerry.com. 


\section{REFERENCES}

Aguilera, R.V., Rupp, D.E., Williams, C.A. and Ganapathi, J. (2007), "Putting the S back in corporate social responsibility: A multi-level theory of social change in organizations”, Academy of Management Review, Vol 32 No 3, pp. 836-863.

Alexander, G. and Buchholz, R. (1982), “Corporate social responsibility and stock Market performance”, Academy of Management Journal, Vol 21 No 3, pp. 479-486.

Amit, R. and Schoemaker, P. (1993), “Strategic assets and organisational rents”, Strategic Management Journal, Vol 4 No 1, pp. 33-47.

Andrews, K.R. (1971), The Concept of Corporate Strategy, Dow-Jones Irwin, Homewood, IL.

Ansoff, H.I. (1965), Corporate Strategy, McGraw-Hill, New York, NY.

Ansoff, H.I. (1980), “Strategic issues management”, Strategic Management Journal, Vol 1 No 2, pp. 131-148.

Bain, J.S. (1959), Industrial Organization, John Wiley \& Sons, New York, NY.

Barnard, C.I. (1938), The Functions of Executives, Harvard University Press, Cambridge, MA.

Barney, J.B. (1991), "Firm resources and sustained competitive advantage”, Journal of Management, Vol 17 (Special Issue), pp. 99-120.

Barney, J.B. and Hansen, M. (1994), “Trustworthiness as a source of competitive advantage”, Strategic Management Journal, Vol 15 (Special Issue), pp. 175-190.

Bearden, B., Ingram, T. and LaForge, B. (2003), Marketing: Principles and Perspectives ( $4^{\text {th }}$ ed), McGraw-Hill/Irwin, New York, NY.

Bennett, R. (1996), Corporate Strategy and Business Planning, Pitman Publishing, London. 
Bloch, H. and Finch, J. (2005), “Penrose and Steindl: Foundations for a general theory of firms and competition”, Working Paper Series 05:07, School of Economics and Finance, Curtin University of Technology.

Burke, L. and Logston, J.M. (1996), “How corporate responsibility pays off”, Long Range Planning, Vol 29 No 4, pp. 495-502.

Burros, M. (2006), "KFC is sued over the use of trans fats in its cooking," New York, NY Times, 14 June, p. A14.

Cahill, D.J. (1997), “Target marketing and segmentation: Valid and useful tools for marketing”, Management Decision, Vol 35 No 1, pp. 10-13.

Carlisle, Y.M. and Faulkner, D.O. (2004), “Corporate social responsibility: A stages framework”, European Business Journal, Vol 16 No 4, pp. 143-152.

Carroll, A.B. (1979), “A three-dimensional conceptual model of corporate performance”, Academy of Management Review, Vol 4 No 4, pp. 497-505.

Carroll, A.B. (1991), “The pyramid of corporate social responsibility: Toward the moral management of organizational stakeholders”, Business Horizons, Vol 34 No 4, pp.39-48.

Carroll, A.B. (1999), “Corporate social responsibility: Evolution of a definitional construct”, Business and Society, Vol 38 No 3, pp. 268-295.

Chan Kim, W. and Mauborgne, R. (2004), “Blue ocean strategy”, Harvard Business Review, Vol 82 No 10, pp. 76-84.

Clarkson, M.B.E. (1995), “A stakeholder framework for analysing and evaluating corporate social performance”, Academy of Management Review, Vol 20 No 1, pp. 92-117. 
Davies, R. (2003), “The business community: Social responsibility and corporate values”, in Dunning, J.H. (Ed.), Making Globalisation Good - The Moral Challenges of Global Capitalism, Oxford University Press, New York, NY.

Davis, I. (2005), “What is the business of business?”, McKinsey Quarterly, No. 3, pp. 105-113.

Day, G.S. (1994), “The capabilities of market-driven organisations”, Journal of Marketing, Vol 58 No 4 pp. 37-52.

Day, G.S. (1999), The Market Driven Organization, The Free Press, New York, NY.

Dierickx, I. and Cool, K. (1989), “Asset stock accumulation and sustainability of competitive advantage”, Management Science, Vol 35 No 12, pp. 1504-1511.

Donaldson, T. and Dunfee, T. W. (1994), “Toward a unified conception of business ethics: Integrated social contract theory”, Academy of Management Review, Vol 19 No 2, pp. 252-284.

Donaldson, T. and Dunfee, T. W. (1999), Ties That Bind. A Social Contracts Approach to Business Ethics, Harvard Business School Press, Boston, MA.

Donaldson, T. and Preston, L.E. (1995), "The stakeholder theory of the corporation: Concepts, evidence, and implications”, Academy of Management Review, Vol 20 No 1, pp. 65-91.

Drucker, P.F. (1954), The Practice of Management, Harper and Row, New York, NY.

Fombrun, C. and Shanley, M. (1990), "What's in a name? Reputation building and corporate strategy”, Academy of Management Journal, Vol 33 No 2, pp. 233-258.

Freeman, E. (1984), Strategic Management: A Stakeholder Approach, Pitman, Boston, MA.

Friedman, M. (1970), “The social responsibility of business is to increase its profits”, New York, NY Times Magazine, 13 September, pp. 32-33, 122, 124, 126. 
Gale, B.T. (1994), Managing Customer Value, The Free Press, New York, NY.

Hamel, G. and Prahalad, C.K. (1994), Competing For the Future, Harvard Business School Press, Cambridge, MA.

Henderson, D. (2005), “The role of business in the world today”, Journal of Corporate Citizenship, Vol 17 (Spring), pp. 30-32.

Hill, C.W.L. and Deeds, D.L. (1996), “The importance of industry structure for the determination of firm profitability: A neo-Austrian perspective”, Journal of Management Studies, Vol 33 No 4, pp. 429-451.

Hirschland, M. (2005), Taking the Temperature of CSR Leaders, Business for Social Responsibility, San Francisco, CA.

Hosmer, L.T. (1994), “Strategic planning as if ethics mattered”, Strategic Management Journal, Vol 15 (Special Issue), pp. 17-34.

Hosmer, L.T. (1995), “Trust: The connecting link between organization theory and philosophical ethics”, Academy of Management Review, Vol 20 No 2, pp. 379-403.

Hult, G.T.M. and Ketchen, D.J., Jr. (2001), “Does market orientation matter? A test of the relationship between positional advantage and performance”, Strategic Management Journal, Vol 22 No 9, pp. 899-906.

Huselid, M. (1995), “The impact of human resource management practices on turnover, productivity, and corporate financial performance”, Academy of Management Journal, Vol 38 No 3, pp. 635-672.

Husted, B.W. and Salazar, J. (2006), “Taking Friedman seriously: Maximizing profits and social performance”, Journal of Management Studies, Vol 43 No 1, pp. 75-91.

Jacobson, R. (1992), “The 'Austrian’ school of strategy”, Academy of Management Review, Vol 17 No 4, pp. 782-807. 
Jones, T. (1995), “Instrumental stakeholder theory: A synthesis of ethics and economics”, Academy of Management Review, Vol 20 No 2, pp. 404-437.

Kahaner, L. (1996), Competitive Intelligence, Simon and Schuster, New York, NY

Khurana, R., Nohria, N. and Penrice, D. (2005), “Management as a profession”, in Dorsch, J. W., Zelleke, A., and Berlowitz, L. (Eds.), Restoring Trust in American Business, American Academy of Arts and Sciences, Cambridge, MA.

Kohli, A.K. and Jaworski, B.J. (1990), "Market orientation: The construct, research propositions, and managerial implications”, Journal of Marketing, Vol 54 No 2, pp. $1-18$.

Kotler, P. (1991). Marketing Management, Prentice Hall, Englewood Cliffs, NJ.

Kotler, P. and Armstrong, G. (2005), Principles of Marketing (11 ${ }^{\text {th }}$ ed.), Prentice Hall, Englewood Cliffs, NJ.

Lamertz, K., Martens, M. and Heugens, P. P. M. A. R. (2003), "Issue evolution: A symbolic interactionist perspective”, Corporate Reputation Review, Vol 6 No 1, pp. 82-93.

Lantos, G.P. (2002), “The ethicality of altruistic corporate social responsibility”, Journal of Consumer Marketing, Vol 19 No 2/3, pp. 205-228.

Lawrence, R.G. (2004), “Framing obesity: The evolution of news discourse on a public health issue”, The Harvard International Journal of Press/Politics, Vol 9 No 3, pp. 56-75.

Learned, E.P., Christensen, C.R., Andrews, K.R. and Guth, W.D. (1969), Business Policy: Text and Cases (Rev. ed.), Richard D. Irwin, Homewood, IL.

Logsdon, J. and Wood, D. J. (2002), “Business citizenship: From domestic to global level of analysis”, Business Ethics Quarterly, Vol 12 No 2, pp. 155-188. 
Mackey, A., Mackey, T. B. and Barney, J.B. (2007), “Corporate social responsibility and firm performance: Investor preferences and corporate strategies”, Academy of Management Review, Vol 32 No 3, pp. 817-835.

Mahon, J. F. and Waddock, S. A. (1992), “Strategic issues management: An integration of issue life cycle perspectives”, Business and Society, Vol 31 No 1, pp. 19-33.

Maignan, I., Ferrell, O.C. and Hult, G.T.M. (1999), “Corporate citizenship: Cultural antecedents and business benefits”, Journal of the Academy of Marketing Science, Vol 27 No 4, pp. 455-469.

Marshall, A. (1919), Industry and Trade, Macmillan, London.

Marshall, A. (1920), Principles of Economics ( $8^{\text {th }}$ ed.), Macmillan, London.

Matten, D. and Crane, A. (2005), “Corporate citizenship: Toward an extended theoretical conceptualisation”, Academy of Management Review, Vol 30 No 1, pp. 166-179.

McKinsey and Company (2006), The McKinsey Global Survey of Business Executives: Business and Society, McKinsey and Company, New York, NY.

McWilliams, A. and Siegel, D. (2001), “Corporate social responsibility: A theory of the firm perspective”, Academy of Management Review, Vol 26 No 1, pp. 117-127.

Merton, R. (1957), Social Theory and Social Structure, The Free Press, Glencoe, IL.

Mintzberg, H. (1987), “Crafting strategy”, Harvard Business Review, Vol 65 No 4, pp. 66-74.

Mullen, J. (1997), "Performance-based corporate philanthropy: How 'giving smart' can further corporate goals”, Public Relations Quarterly, Summer, pp. 42-48.

Murray, K.B. and Montanari, J.R. (1986), "Strategic management of the socially responsible firm: Integrating management and marketing theory”, Academy of Management Review, Vol 11 No 4, pp. 815-827. 
Narver, J.C. and Slater, S.F. (1990), “The effect of a market orientation on business profitability,” Journal of Marketing, Vol 54 No 4, pp. 20-35.

Nelson, R.R. and Winter, S.G. (1982), An Evolutionary Theory of Economic Change, Harvard University Press, Cambridge, MA.

Normann, R. and Ramirez, R. (1993), “From value chain to value constellation: Designing interactive strategy”, Harvard Business Review, Vol 71 No 4, pp. 65-77.

Ogburn, W.F. (1964), On Culture and Social Change, University of Chicago Press, Chicago, IL.

Orlitzky, M., Schmidt, F. L. and Rynes, S. L. (2003), “Corporate social and financial performance: A meta-analysis”, Organization Studies, Vol 24 No 3, pp. 403-441.

Paine, L. S. (2002), Value Shift, McGraw-Hill, New York, NY.

Pearce, J.A., II. and David, F. (1987), “Corporate mission statements: The bottom line”, The Academy of Management Executive, Vol 1 No 2, pp. 109-116.

Pearce, J.A., II. and Doh, J.P. (2005), “The high impact of collaborative social initiatives”, MIT Sloan Management Review, Vol 46 No 3, pp. 30-39.

Peteraf, M. and Shanely, M. (1997), “Getting to know you: A theory of strategic group identity”, Strategic Management Journal, Vol 18 (Special Issue), pp. 165-86.

Porter, M. E. (1980), Competitive Strategy, The Free Press, New York, NY.

Porter, M. E. (1985), Competitive Advantage, New York, NY, The Free Press.

Porter, M.E. (1991), “Towards a dynamic theory of strategy”, Strategic Management Journal, Vol 12 (Special Issue), pp. 95-117.

Porter, M.E. (1996), “What is strategy?”, Harvard Business Review, Vol 74 No 6, pp. 6178.

Porter, M.E. and Kramer, M.R. (2002), “The competitive advantage of corporate philanthropy”, Harvard Business Review, Vol 80 No 12, pp. 56-68. 
Posner, B. Z. and Schmidt, W. H. (1984), "Values and the American manager: An update”, California Management Review, Vol 26 No 3, pp. 202-216.

Prahalad, C.K. (1997), “Corporate governance or corporate value added? Rethinking primacy of shareholder value”, in Chew, D. (Ed.), Studies in International Corporate Finance and Governance Systems, Oxford University Press, New York, NY.

Prahalad, C.K. and Hamel, G. (1990), “The core competence of the corporation”, Harvard Business Review, Vol 68 No 3, pp. 79-91.

Raimond, P. (1996), “Two styles of foresight: Are we predicting the future or inventing it?”, Long Range Planning, Vol 29 No 2, pp. 208-214.

Rodriguez, M. A., Richart, J. E. and Sanchez, P. (2002), "Sustainable development and the sustainability of competitive advantage: A dynamic and sustainable view of the firm”, Creativity and Innovation Management, Vol 11 No 3, pp. 135-146.

Rumelt, R. (1980), “The evaluation of business strategy”, In W.G. Glueck, Business Policy and Strategic Management ( $3^{\text {rd }}$ ed.), McGraw-Hill, New York, NY.

Schendel, D. and Hofer, C. (1979), Strategic Management, Little, Brown, Boston, MA.

Schumpeter, J.A. (1934). The Theory of Economic Development (2 ${ }^{\text {nd }}$ ed.), Harvard University Press, Cambridge, MA.

Sethi, S.P. (2003), “Globalization and the good corporation: A need for proactive coexistence”, Journal of Business Ethics, Vol 43 No 1/2, pp. 21-31.

Sheth, J.N., Gardner, D.M. and Garrett, D.E. (1988), Marketing Theory: Evolution and Evaluation, John Wiley \& Sons, New York, NY.

Slater, S.F. (1997), “Developing a customer value-based theory of the firm”, Journal of the Academy of Marketing Science, Vol 25 No 2, pp. 162-167.

Steiner, G. (1979), Strategic Planning, The Free Press, New York, NY. 
Swartz, P. (1996), The Art of the Long View, Currency Doubleday, New York, NY.

Teece, D.J., Pisano, G. and Shuen, A. (1997), "Dynamic capabilities and strategic management”, Strategic Management Journal, Vol 18 No 7, pp. 509-533.

The Work Foundation. (2002), Managing Best Practice: Corporate Social Responsibility, The Work Foundation, London.

Vyakarnam, S. (1992), “Social responsibility: What leading companies do”, Long Range Planning, Vol 25 No 5, pp. 59-67.

Weaver, G. R., Treviño, L. K. and Cochran, P. L. (1999), "Integrated and decoupled corporate social performance: Management commitments, external pressures, and corporate ethics practices”, Academy of Management Review, Vol 42 No 5, pp. 539552.

Wernerfelt, B. (1984), “A resource-based view of the firm”, Strategic Management Journal, Vol 5 No 2, pp. 171-180.

Williamson, O.E. (1985), The Economic Institutions of Capitalism, The Free Press, New York, NY.

Windsor, D. (2001), “The future of corporate social responsibility”, International Journal of Organizational Analysis, Vol 9 No 3, pp. 225-256.

Zeithaml, V.A. (1988), “Consumer perceptions of price, quality, and value: A means-end model and synthesis of evidence”, Journal of Marketing, Vol 52 No 3, pp. 2-22. 


\section{FIGURES}

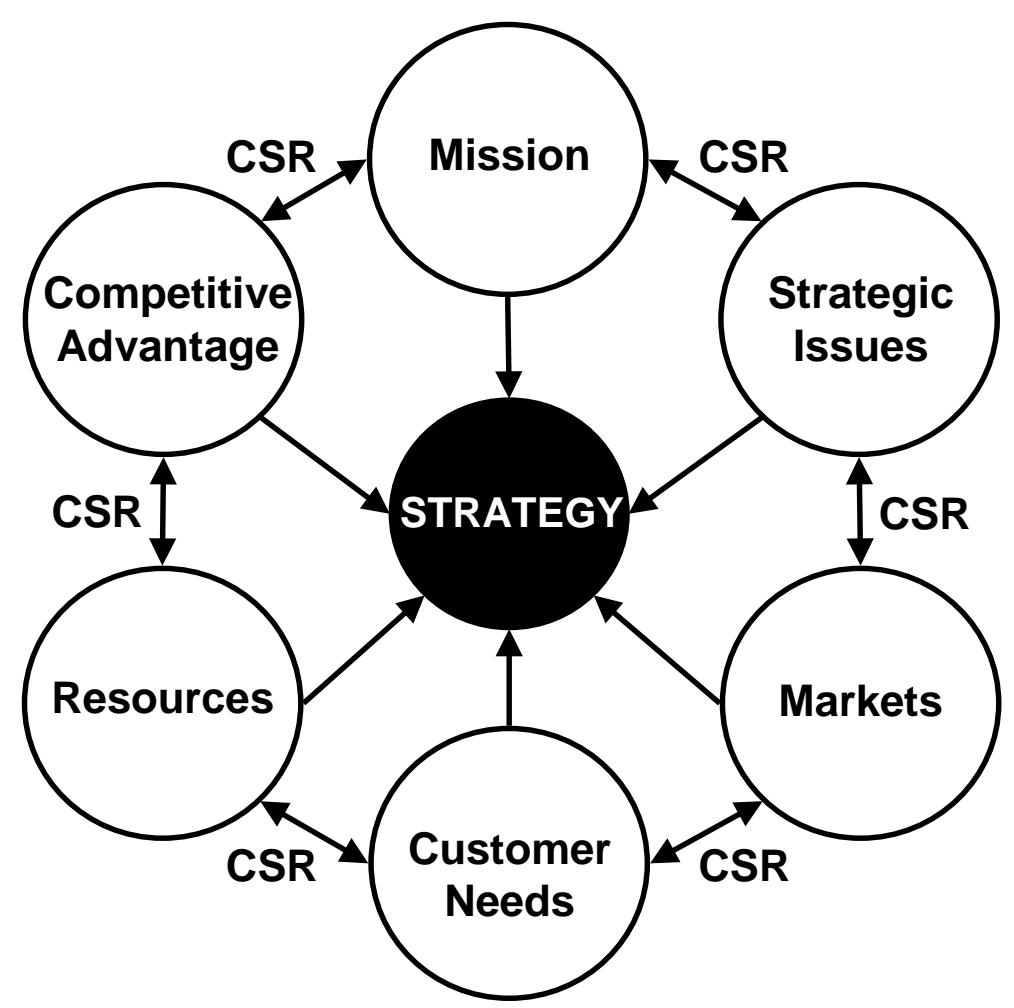

Figure 1. CSR in the context of strategy 


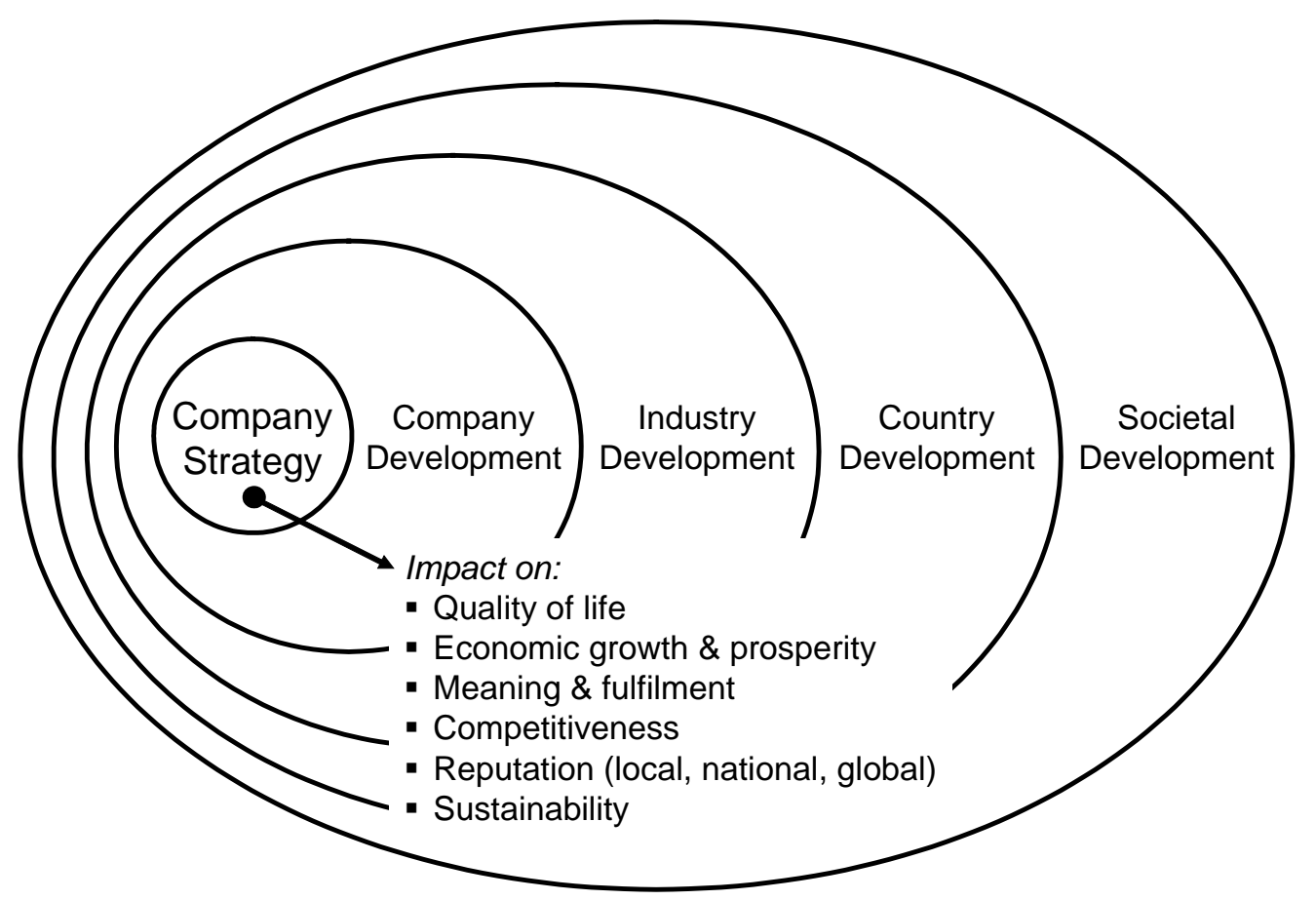

Figure 2. Strategy in the context of society 